\title{
Appraisal of Fluoride Concentration, Distribution and Geogenic Origin in Ground and Surface Water from Semi-Arid Region, Part of Yobe State North-eastern Nigeria
}

\author{
Mohammad Yerima Kwaya ${ }^{1}$, Hamidu Hassan ${ }^{1,}$, , Jibrin Umar ${ }^{2}$, Kachalla Musa ${ }^{3}$ \\ ${ }^{1}$ Department of Geology, Faculty of Sciences, Usmanu Danfodiyo University, Sokoto, Nigeria \\ ${ }^{2}$ Department of Civil Engineering Technology, Faculty of Engineering, Federal Polytechnic, Damaturu, Nigeria \\ ${ }^{3}$ African Development Bank-Assisted Rural Water Supply and Sanitation, Yobe State Sub-Programme, Damaturu, Nigeria
}

\author{
Email address: \\ hassanhamidu@yahoomail.com (H. Hassan) \\ ${ }^{*}$ Corresponding author
}

\section{To cite this article:}

Mohammad Yerima Kwaya, Hamidu Hassan, Jibrin Umar, Kachalla Musa. Appraisal of Fluoride Concentration, Distribution and Geogenic Origin in Ground and Surface Water from Semi-Arid Region, Part of Yobe State North-eastern Nigeria. Hydrology.

Vol. 5, No. 6, 2017, pp. 96-101. doi: 10.11648/j.hyd.20170506.13

Received: January 25, 2017; Accepted: February 9, 2017; Published: January 10, 2018

\begin{abstract}
The Fluoride concentration of water sources from part of Yobe State has been investigated, Fluoride levels in Pond water is between 0.71 and $1.36 \mathrm{mg} / \mathrm{l}$, Dugwells concentration is from 0.00 to $1.5 \mathrm{mg} / \mathrm{l}$. The sampled water from tube wells and boreholes have concentrations ranges of $0.65-1.5 \mathrm{mg} / 1$ and $0.00-2.2 \mathrm{mg} / 1$ respectively with the level of concentration being a function of depth. Health risk assessment have revealed three classes of risk in terms of Fluoride concentration levels in the water with 16 samples representing $14.3 \%$ falling within the Risk class of $1.5 \leq \mathrm{R} \leq 2.5$ (risk). Individual consuming such water have the tendency of getting dental fluorosis. Origins of Fluoride in the water are from Fluoride bearing minerals like Micas, Amphiboles, Illites, Apatite, Topaz, and Cryolite which occur in the sandy and clayey layers, anthropogenic sources from agricultural and irrigated land and leachate from dumps are the other possible sources of Fluoride in the tube wells and ponds water respectively. The dissolution, distribution and concentration of Fluoride in groundwater in the area are favoured by the high temperature high evapotranspiration rate and low rainfall situation of the semi-arid climate. Geochemical situation that allowed the leaching of Fluoride into the water are; high Alkaline or soda water environment, anion exchange of $\mathrm{OH}$ for $\mathrm{F}$ of the aquifer material, water residence time in the aquifer and type of climate. Drab and Sierozem Soil types control and facilitate the mobility and leaching of Fluoride in arid and semi-arid area. Generally the result has shown the area to have medium to average concentration of Fluoride in its waters with the highest value slightly above the $1.5 \mathrm{mg} / \mathrm{l}$ of WHO (2011) safe limit for drinking water. Periodic monitoring of Fluoride in the water sources is recommended so as to minimize the chances of people taking in water with high undesirable harmful Fluoride concentration.
\end{abstract}

Keywords: Geogenic Origin, Semi-Arid Area, Groundwater, Fluoride Bearing Minerals, Fluvial-Lacustrine Sediment, Yobe State

\section{Introduction}

Fluorine is a member of the Halogen family of group (VII) of the periodic table of elements. Being the most chemically active element among its pairs and a strong oxidant, it does not occur in the free elemental state in nature. It account for about $0.3 \mathrm{~g} / \mathrm{kg}$ of the earth's crust were it exists as Fluoride in a number of minerals like Fluorspar, Cryolite, Fluoroapatite,
Fluorite, Villiaumite, Silicates Micas, Apatite, Amphiboles and Topaz, [1], [2], [3] and [4]. These minerals can occur either as evaporates or detrital grains in sedimentary rocks or as Composition of crystalline rocks in bedrock aquifers, still it is considered a trace or less abundant element on earth because it constitute only $0.06-0.09 \%$ of the earth crust, [5]. Fluoride concentration in groundwater or in an aquifer will solely depend on factors which includes among others, fluoride concentration of the minerals in the surrounding, 
mineral decomposition, dissociation and dissolution rates, resident time of groundwater in the rock or aquifer and the reaction kinetics, these factors will determine the solubility of Fluorite in the water in a given type of aquifer, [6]. [7] Pointed out that more than 260 million people in the world take in water with Fluorite concentration of more than 1.0 $\mathrm{mg} / \mathrm{l}$ with majority of them residing in the tropical countries with arid and humid climate conditions.

The study of Fluoride in water sources is vital because of it positive and negative side effects on both human and animal health. The positive benefits of fluorides intake in drinking water is that of prevention of tooth decay and Caries in children, Concentration level of less than $0.5 \mathrm{mg} / \mathrm{l}$ in water can lead to the risk of tooth decay. [4] Showed that Fluoride concentration bellow $0.5 \mathrm{mg} / \mathrm{l}$ in water is completely absorbed by the body hence leading to dental fluorosis which causes the staining, weakening and eventual loss of teeth. Concentration of between 0.5 and $1.00 \mathrm{mg} / \mathrm{l}$ of Fluoride can prevent or reduces tooth decay and Caries. For tooth paste preparation concentration of $0.25-1.00 \mathrm{mg} / \mathrm{l}(1000-1500$ per $\mathrm{kg}$ of tooth paste is needed for prevention of Caries, A Fluoride intake of 3 $\mathrm{mg} \mathrm{f} /$ day has being recommended by [1]. Negative harmful effects of high Fluoride consumption in water studied, elevated Fluoride intake of 3-6 mg/l can lead to skeletal fluorosis (change in bone structure) and crippling skeletal fluorosis will occur when concentration of $10 \mathrm{mg} / \mathrm{l}$ is taken in water [8].

[9] evaluated the contamination of groundwater from Ibadan town; they recorded a Flouride concentration level range of 1.82 to $6.38 \mathrm{mg} / \mathrm{l}$ with an average of value of $3.37 \mathrm{mg} / 1$ for the groundwater from the crystalline aquifer. [10] investigated the occurrence of Flouride in the drinking water of Langtang, a concentration range of 0.12 to 10.30 $\mathrm{mg} / \mathrm{l}$ with a mean of $2.42 \mathrm{mg} / \mathrm{l}$ was obtained, they identified sources of the Flouride in the water to be mica mineral present in the host rocks and pegmatite because of the positive correlation between the Flouride and lithium minerals. Cases of dental fluorosis and leg bowing common in the area indicated the high Flouride from drinking water. [11] also studied the distribution of Flouride in the major aquifers of Northern Nigerian; they recorded a concentration range of 0.03 to $10.30 \mathrm{mg} / \mathrm{l}$ for the basement aquifers, 0.00 to $5.00 \mathrm{mg} / \mathrm{l}$ was recorded for the sedimentary aquifers while the younger granites Fluoride concentration in the granite aquifers range between 0.00 and $0.89 \mathrm{mg} / \mathrm{l}$. They discovered a positive correlation between dental fluorosis and high fluoride water intake, with the Basement and Sedimentary aquifers of Northeastern Nigeria having the higher Flouride concentration level above the 1.5 maximum permissible levels, generally the northwestern sedimentary basin have low Flouride concentration level in their water.

[12] investigated the distribution of Flouride in the drinking water of Kaltungo area, they obtained a concentration that ranges between 0.52 to $4.4 \mathrm{mg} / \mathrm{l}$ and 0.1 to $3.95 \mathrm{mg} / \mathrm{l}$ for both surface and groundwater sources with an average of $2.8 \mathrm{mg} / \mathrm{l}$, their findings revealed that people in the area are at a high risk of consuming water with high fluoride and has resulted in cases of dental fluorosis in individuals in the area. [13] studied the suitability of both surface and groundwater for different uses in Boh community of Shongom local government area in Gombe state, they obtained a Fluoride concentration range of between 0.42 to $1.72 \mathrm{mg} / \mathrm{l}$ which is above the background value of $1.00 \mathrm{mg} / \mathrm{l}$ and the $1.5 \mathrm{mg} / \mathrm{l}$ maximum permissible limit, they indicated the origin /sources of these ions in the water to be the different rock units in the area. [14] in their study on lithological influence on the hydrogeochemical characteristics in Zango Katsina State; presented a fluoride concentration range of 0.10 and $3.16 \mathrm{mg} / \mathrm{l}$ with a mean of $0.94 \mathrm{mg} / \mathrm{l}$ for the dry season period while a range of 0.10 to $1.47 \mathrm{mg} / \mathrm{l}$ was obtained for the wet period with an average of $0.523 \mathrm{mg} / \mathrm{l}$. Concentrations above the $1.5 \mathrm{mg} / \mathrm{l}$ was obtained from groundwater in the younger granites aquifers, they also identified the fluoride source to be from the dissolution of the granite rock, however cases of dental fluorosis were observed in the area.[15] and[16] recorded a Fluoride concentration of $5.6 \mathrm{mg} / \mathrm{l}$ in the groundwater from the upper aquifer of Chad basin in Maiduguri area of Borno State.

[17], determined the trace elements in the municipal water supply in Damaturu town, fluoride concentration measured for a dug well at Powari community was $0.48 \mathrm{mg} / 1$ and the value obtained for a borehole at Hausari area was $0.35 \mathrm{mg} / \mathrm{l}$ these values indicates a low and safe fluoride in the analysed samples. [18] Assessed the fluoride levels in the surface and groundwater from Borno and Yobe states in the Northeastern Nigeria, their findings showed that the groundwater fluoride concentration is $0.02-2.42 \mathrm{mg} / \mathrm{l}$ while the surface water has a concentration range of between 0.03 and $2.07 \mathrm{mg} / 1$ with $43 \%$ of the samples having their concentrations above the $1.5 \mathrm{mg} / 1$ limit. It is based on this background information on the implication of Flouride in north eastern Nigeria that prompt this present research work to be carried out in the proposed area because of its location within the zone of high Flouride concentration in drinking water and with prevailing cases of dental fluorosis and other related abnormalities cause by high Flouride intake from drinking water.

\section{Materials and Methods}

\subsection{The Study Area}

All the nine local governments' areas which comprise the study area are located in the northeastern state of Yobe. Yobe State is located within the semi-arid region of northeastern Nigeria, with the following coordinate: Latitudes $10^{\circ} 55^{\prime}$ and $13^{\circ}$ $40^{\prime}$ and Longitudes $9^{\circ} 45^{\prime}$ and $12^{\circ} 29^{\prime}$ Figure 2. There are two distinct seasons, a short wet season of four months which is between June and October, [19], with temporal and spatial distribution of low rainfall of about $1000 \mathrm{~mm}$ at the southern part of the state to less than $500 \mathrm{~mm}$ at extreme northern part of the state, while the long dry season which normally lasts for seven months is characterized by dry and hot climatic conditions with an annual average temperature of about $32^{\circ} \mathrm{C}$. Mean annual evaporation is $1600 \mathrm{~mm}$, [20]. Vegetation is typical of Sudan type with sparsely distributed short trees and shrubs, soil type is 
the vertisols which is heavy and dark with the land elevation ranging between 100 to $300 \mathrm{~m}$ above sea level.

\subsection{Geology and Hydrogeology of the Area}

The geology of the area is similar with that of Chad Basin, the geology of Yobe area consist of Precambrian Basement complex rocks and the cretaceous Sedimentary Chad basin, [21 distinguished three different phases for the Pan African Older granites in the Northeastern Nigeria these are Basic and intermediate plutonic, the fine grained granites and the syntectonic granites. These are rich in potash which occurs as microcline phenocryst. The plutonic variety occur as irregular bodies of gabbro, quartz-diorite and granodiorites, while the fined grained granites occur as minor discordant intrusions, the syntectonic type of granites occur as anatectic migmatites or equigranuler and porphyritic semi concordant granites. The Volcanics in the area are represented by basalts, trachyte and rhyolites. The Cretaceous sedimentary rocks in the study area from the top to bottom are represented by the following sequence. Chad formation which consist of sands and clays units of upper pliocene- pleiscene in age it is a fluviatile and lacustrine deposit of thickness of 1,500 $\mathrm{m}$ deep, this is follow by the Kerri-Kerri formation unconformably overlies the Gombe sandstone this consists of grits, sands, clays and oolitic sands deposited in a lacustrine/deltaic environment this formation is Paleocene in age with estimated thickness of about $130 \mathrm{~m}$, [21]. Gombe sandstone underlies the Kerri-Kerri and this is mainly composed of sandstone, siltstone, shale and ironstone it is Maastrichtian in age. A transitional sequence of Gongila formation underlies the Gombe sandstone it is mainly a bed of sandstone, calcareous shale, limestone and Silty sandstone deposited under shallow marine environment during the Turonian, well log interpretation by various researchers has revealed a thickness range of $420-1,410 \mathrm{~m}$ for the Gongila. The Fika shales are Senonian in age and are made up of blue shales, poorly exposed with a cotton soil feature and gypsiferous, [22], deposited under deep marine environment, a thickness range of between 430 to $1,453 \mathrm{~m}$ have being recorded for this formation by different authors, Obaje [23]. The AptianAlbian Bima Sandstone which was deposited in fluvial environment is the oldest sedimentary formation in the area, it unconformably lies on the Pre Cambrian Basement in the area. In most parts of the study area the Gombe Sandstone and the Chad formation are either very thin or completely absent thereby exposing the Kerri-Kerri formation to the surface, figure 1 .

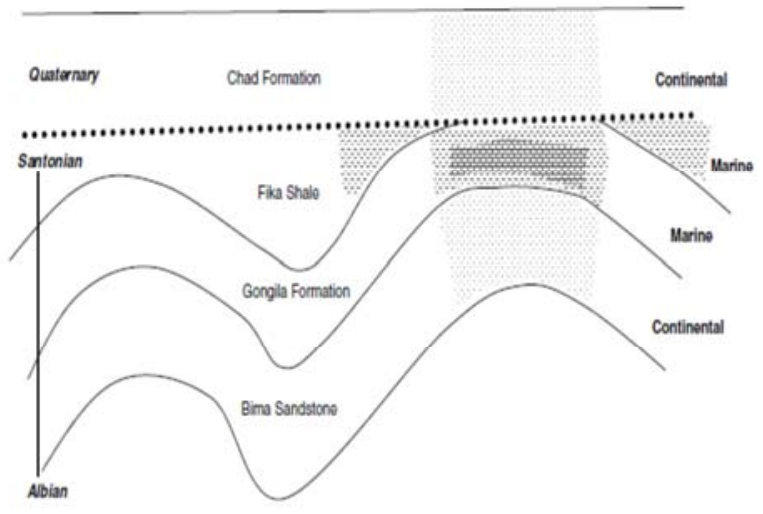

Figure 1. Stratigraphic successions in the Nigerian sector of the Chad Basin adopted from Obaje(2009).

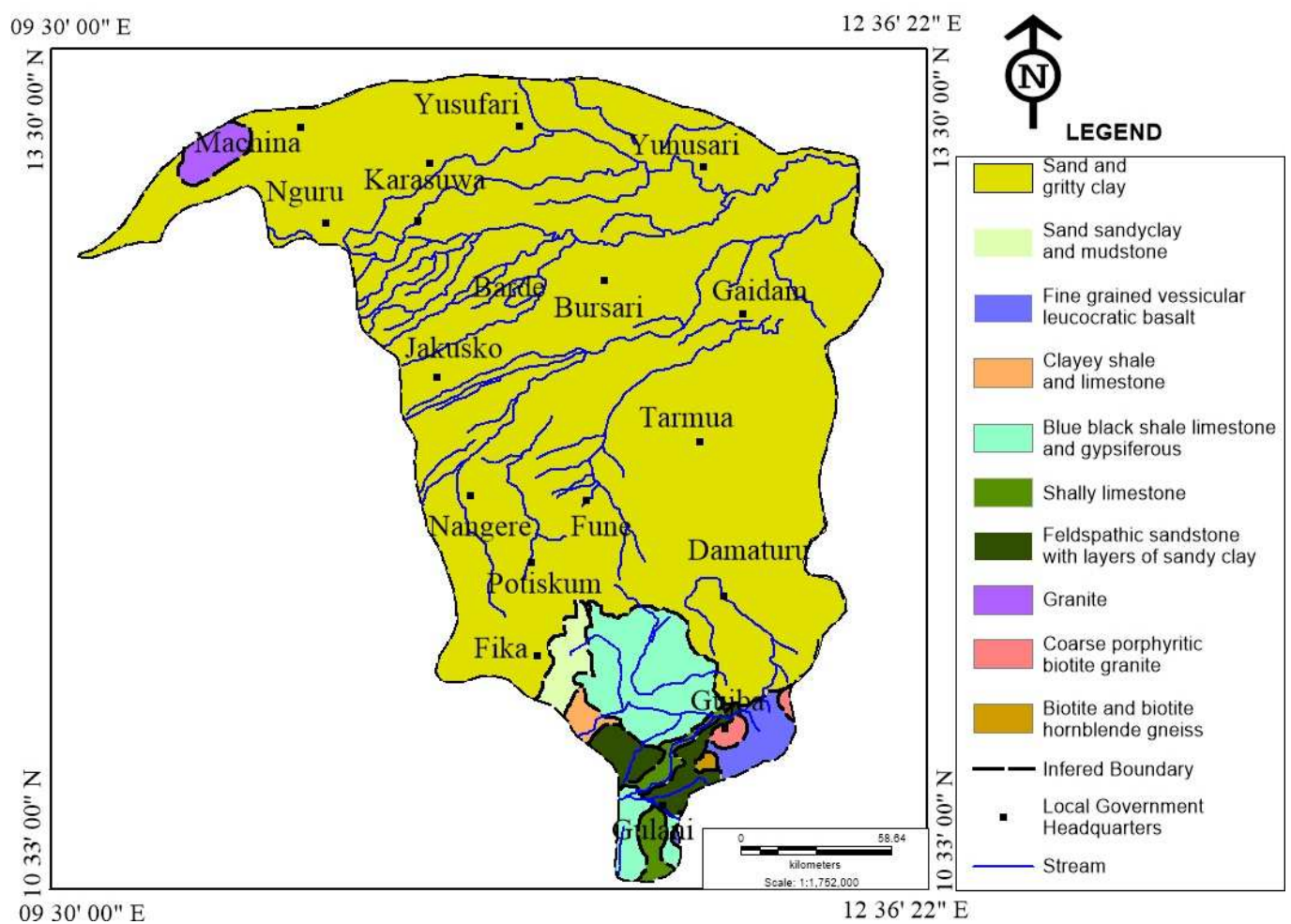

Figure 2. Geologic Map of Yobe State showing the local government areas of study modified from the geology and mineral map of Yobe State of the Nigerian Geological Survey Agency (2006). 
For groundwater system in the area four Aquiferous layers have been identified, out of these only two contain appreciable quantity of water these include a second layer of sandy soil within the Chad formation with thickness range of between 80- $150 \mathrm{~m}$, boreholes tapping water from this formation have a yield that ranges between 8 and 101/s with conductivity of less than $10 \mathrm{~m} /$ day to $65 \mathrm{~m} /$ day, [19]. The second water bearing layer in the area is within the KerriKerri formation and is made of aquifer materials that consists of sandstones. These aquifers are recharge through precipitation with a value range of 16- $30 \mathrm{~mm} /$ year, [19]. For areas like Machina and Gulani with younger granite and volcanic intrusion of basement rocks, groundwater occurs in the fractured bedrock and weathered mantle, Yield of wells is control by depth of weathering intensity and connectivity of fractures, geology and mineral composition of the parent rock. As far as groundwater potentials is concern the Chad and Kerri-Kerri formations are the highly water bearing formations.

\subsection{Water Sampling and Analysis}

Water samples were collected from four different sources which includes Boreholes, Tube wells, Dug wells and Ponds and analysed for the presence of Fluoride ion. In all 112 water samples were collected, each in a little plastic bottle container from nine local government areas of Yobe State. Each sampling container was rinsed at the sampling point with the sources water before collecting and transported to water control laboratory of Yobe State ministry of water resources in Damaturu for analysis. A Dr/200(Hach) Spectrophotometer was used for the detection of Fluoride in the water samples after preparation. The analysed samples were then interpreted.

\section{Results and Discussions}

The summary of the result in given in Table 1

Table 1. Summary of Fluoride Concentration Obtained from the Study Area.

\begin{tabular}{|c|c|c|c|c|c|c|}
\hline \multirow{2}{*}{ S/NO } & \multirow[t]{2}{*}{ Local Government Area } & \multicolumn{5}{|c|}{ Concentration and Ranges of Fluoride in Water Sources From the Study Area in (mg/l) } \\
\hline & & $0.00-0.52$ & $0.60-0.98$ & 1.00-1.50 & 2.00-2.20 & Total no. of Samples Analysed \\
\hline 1 & Barde & 9 & - & - & - & 9 \\
\hline 2 & Bursari & 3 & 5 & - & - & 8 \\
\hline 3 & Damaturu & 8 & 3 & 5 & - & 16 \\
\hline 4 & Fika & - & 2 & 2 & - & 4 \\
\hline 5 & Gulani & - & 1 & 14 & - & 15 \\
\hline 6 & Karasuwa & 9 & 8 & 6 & - & 23 \\
\hline 7 & Nangere & 4 & - & - & 3 & 7 \\
\hline 8 & Nguru & 10 & 10 & 2 & 1 & 23 \\
\hline 9 & Potiskum & 2 & 2 & 3 & - & 7 \\
\hline & Total & & & & & 112 \\
\hline
\end{tabular}

Out of the 112 water samples analysed Flouride was not detected in only ten samples with four from boreholes and six from dug wells. The four Pond water analysed has Fluoride concentration between 0.71 and $1.36 \mathrm{mg} / \mathrm{l}$ while Dug well values ranges between 0.00 to $1.5 \mathrm{mg} / 1$ for the 18 samples collected. Concentration for the three Tube wells water samples collected from Potiskum local government area ranged between $0.65-1.5 \mathrm{mg} / \mathrm{l}$. Water samples analysed from the 86 Boreholes water samples analysed contain Fluoride that ranges in concentration from 0.00 to $2.2 \mathrm{mg} / \mathrm{l}$. Both the least and highest detectable Fluoride concentration of 0.01 and $2.2 \mathrm{mg} / \mathrm{l}$ were detected from boreholes in the area of study. The result shows the background concentration of 1.00 $\mathrm{mg} / \mathrm{l}$ was recorded from the four types of water sources sampled in this study.

\subsection{Health Implication}

A total of 34 samples out of the samples analysed have a fluoride concentration of bellow $0.6 \mathrm{mg} / \mathrm{l}$. By implication and going by the [1], [8] drinking water standard, there is the likelihood for people taking this water for a longer period of time to develop Dental Caries, especially young Children.
Concentrations of 0.6 to $1.5 \mathrm{mg} / 1$ were obtained from 64 samples this represent $57 \%$ of the analysed water; waters with this range of Fluorite concentration are beneficial because if taken into the body it help in the prevention of Dental Decay and bone development. [24] gave different risk classes based on Fluoride concentration as $0.5 \leq \mathrm{R} \leq 1$ (risk free): $1 \leq \mathrm{R} \leq 1.5$ (slight risk): $1.5 \leq \mathrm{R} \leq 2.5$ (risk): $2.5 \leq \mathrm{R} \leq$ 3.5(high risk) and $\mathrm{R}>3.5$ (very high risk), based on this classification 16 samples representing $14.3 \%$ of the water from this study have Fluoride values that are within the risk class of $1.5 \leq \mathrm{R} \leq 2.5$ (risk) with the probability of individual consuming the water developing dental Fluorosis, while a total 19 of samples representing $16.9 \%$ are within the slightly risk class of $1 \leq \mathrm{R} \leq 1.5$ and the highest number of 85 samples representing $75 \%$ of the water analysed in the area falls in the $0.5 \leq \mathrm{R} \leq 1$ of risk free class. It was observed that the fluorite concentration in the area increases with depth of water sources.

\subsection{Origin and Sources of Fluoride in the Area}

The two main formations forming the aquifers in the study area are the Chad formation (Upper zone) and Kerri-Kerri 
formation aquifers both deposited under fluvial-lacustrine environmental conditions. The semi-arid climate in the area with an extreme high temperature of $42^{\circ} \mathrm{C}$ that result to high evapotranspiration of more than 1600 , an unpredictable and variable low rainfall that falls for 120 to 140 days with an annual range of $<1000$ to $<500$ from the southern to the extreme northern part of the state, is favourable for dissolving fluoride bearing minerals. The most probable origin of Fluoride detected in the water from the area of study area is Geogenic, originating from the dissolution and ejection of Fluorite bearing minerals like micas, amphiboles Illites, Apatite, Topaz or Cryolite in the sandy and clayey layers in these aquifers. Apatite contains florite and occurs as an accessary mineral in sedimentary horizon, [25], weathering process and the circulation of water in rocks and soils leach out Fluoride into the groundwater. Factors that favour the release of Fluoride into groundwater in sediments are the mineralogical composition of the sediment, the extent of sediment alteration and the Geochemistry of the surrounding water, [26]. They authors went further to point out that high Fluoride of clastic sediment is concentrated in micas and clay mineral like Illites, in fluvial sediments the release of Fluoride under acidic condition of low $\mathrm{PH}$ condition is controlled by the dissolution/ alteration of Fluorapatite and biotite minerals originating from fluoride rich igneous and metamorphic rocks. For silicates rich sediments Fluoride dissolution and enrichment in groundwater is principally control by the alkaline $\mathrm{PH}$, anion exchange of $\mathrm{OH}^{-}$for $\mathrm{F}^{-}$capacity of the aquifer materials because of their almost similar ionic radii of $\mathrm{F}$ (1.23-1.36 $\AA$ ) and $\mathrm{OH}(1.37-1.40 \AA)$, cation exchange capacity, and residence time in the aquifer of the groundwater and the climate type, [6], [27].

Fluoride in groundwater can originate from Clays within the aquifer, factors like elevated alkalinity and soil grain size, initial Fluoride concentration in minerals and the salinity favours the desorption of Fluoride from the clay minerals into groundwater, the adsorption capacity of different clay minerals containing Fluoride is given in the order Bentonite $>$ halloysite $>$ gibbsite. Kaolinite $>>$ soap alkaline soil, vermiculite. Goethite; layered silicate mineral $>$ various oxides [26]. Base on the findings of [28] the dominant water type in the Chad basin in Nigeria is the sodium bicarbonate type, this will dissolve and concentrate Fluoride in the groundwater, the mixing up of bicarbonate groundwater with aquifer sediments triggers a reaction that lead to the ejection of Fluoride from the fluorite bearing minerals resulting in the Fluoride becoming enriched in the groundwater, this is represented in equation 1 .

$$
\mathrm{CaF}_{2}+2 \mathrm{NaHCO}_{3} \rightarrow \mathrm{CaCO}_{3}+2 \mathrm{Na}^{+}+2 \mathrm{~F}^{-}+\mathrm{H}_{2} \mathrm{O}+\mathrm{CO}_{2}
$$

The Sodium carbonate water specie facilitate the precipitation of $\mathrm{Ca}_{2}{ }^{+}$and $\mathrm{CO}_{3}{ }^{2+}$ which quickly dissolve the Fluorite $\left(\mathrm{CaF}_{2}\right)$ from the sediment and rock matrix to facilitate the release of Fluoride in the water.

Enrichment of Fluoride into the groundwater is dependent on Soil type, according to [29] the rate of leaching of
Fluoride is related to its movement in different soil type, Drab and Sierozem types of soil favours the leaching of Flouride in arid and semi-arid areas. Beside natural sources anthropogenic sources may be responsible for adding Flouride into the surface Pond water and tube wells water in the area, leached refused dump into these ponds and fertilizer added to farm lands and irrigated areas to increase the soil fertility for the purpose of busting crop yield can add appreciable quantity of Fluoride to these water sources and increase its concentration in water.

\section{Conclusion}

Out of the four sources of water analysed in the area only ten samples are without Fluorite, and this constitute only $8.9 \%$ of the water samples analysed, the remaining 92 samples have concentration of Fluoride that ranges between 0.01 and $2.2 \mathrm{mg} / \mathrm{l}$ with the highest value of $2.2 \mathrm{mg} / \mathrm{l}$ obtained from three boreholes at Nangere local government area. The analysed tube well samples have a Fluoride concentration range of $0.65-1.5 \mathrm{mg} / \mathrm{l}$ while surface Pond water has its highest Fluoride concentration to be $1.36 \mathrm{mg} / \mathrm{l}$. The result shows that there is a good correlation between fluoride concentration and depth. Base on the concentration of the Fluoride detected in the water from this study and the higher concentration of $5.6 \mathrm{mg} / \mathrm{l}$ obtained elsewhere in the same Chad basin by [15] and [16], it can be concluded that the area has medium to average Fluoride level in the water sources. The Fluoride detected in the water originated from the Florite bearing minerals from within the aquifer materials and from other anthropogenic sources.

\section{References}

[1] WHO (2004) Fluoride in Drinking- water. Background document for development of WHO guidelines for drinking water quality: WHO/SDE/WSH/03.04/96.

[2] Veressinina, Y., Trapido,V. A., Munter, R. (2001) Fluorine in drinking water, the problem and its possible solution. Proce: Estonia Acad. Sci. Chem. vol 50: 2 pp 81-88.

[3] Alabdulaay, I. A., Al-Zarah, I. A., Khan, and A. M. (2013) Occurrence of Fluoride in ground waters of Saudi Arabia: Appl water Science journal, 3: 589-595.

[4] Lar, U. A., Dibal, H., Schoneich, K. (2014) Fluoride in groundwater in Nigeria: origin and human health impact: American journal of Environmental protection 3 (6-2) pp 66-69.

[5] Fawell, J. Bailey, K.,Chilton, J., Fewtrell, L., Magar, Y. (2006) Fluoride in drinking water WHO, IWA Publishing, 1-144.

[6] Sexena, V. K., Ahmaed, S. (2001) Dissolution of Fluoride in groundwater: a water- rock interaction study. Environ geol. 40: $1084-1087$.

[7] Shreya, D., Nag, S. K. (2016) Geochemistry appraisal of Fluoride-laden groundwater in Suri I and II Block, Birbhum district, west Bengal. Journal of earth science and climate change, vol: 7 issue 6 pp 1-68. 
[8] WHO (2001) Revision of WHO guidelines for drinking water quality world health organization Geneva.

[9] Egbinola, N. C, Amanambu, C. A (20014) Groundwater contamination in Ibadan, Southwest Nigeria: Springer open journal 3: 448 pp1-6.

[10] Dibal, H. U., Schoenich, k., Garba, I. Lar, U. A., Bala E. A. (2012) Occurrence of Fluoride in the drinking waters of Lang tang area North central Ngeria: Health vol4 No 11 pp 11161126.

[11] Dibal, U. H., Schoenich., k., Garba, I. Lar, U. A., Bala E. A. (2012) Overview of Fluoride distribution in major aquifer units of northern Nigeria: Health vol 4 No 12 pp 1287-1294.

[12] Haruna, I. A., Muhammed,. U., Muhammed, A. A (2014) Environmental distribution of fluoride in drinking waters of Kaltungo area northeastern Nigeria: American journal of environmental protection. 3 (6-2) 19-24.

[13] Lovelyn, S. K., Hamidu, H., Mbiimbe, E. Y., Sidi, M. W., Farida,G. I. (2016) Suitability of ground and surface water resources for different uses in Boh community Gombe state Northeastern Nigeria: nature and science journal 14 (2) pp 2231 .

[14] Amadi, A. N., Aminu, T., Okunlola, I. A., Olasehinde,P. I., Jimoh, M. O. (2015) Lithological influence on the hydrogeochemical characteristics of groundwater in Zango, northwestern Nigeria, natural resources and conservation 3 (1): pp 11-18.

[15] Edmunds, W. M., Fellman, E., Goni, I. B., McNeil, G., Harkness, D. D. (1998) Groundwater palaeoclimate and recharge in the southwest Chad Basin, Borno state, Nigeria. In. Isotopes technique in the study of environmental change. Proceedings of an international symposium, IAEA, Vienna, 1997.

[16] Edmunds, W. M., Fellman, E., Goni, I. B. (1999). Lakes, groundwater and palaeohydrology in the Sahel of NE Nigeria: Evidence from hydrogeochemistry. Journal of geological society of London, 156. pp 345-355.

[17] Emeka,D. O., Weltime, O. M. (2008) Trace elements determination in municipal water supply in Damaturu metropolis Yobe state: Bayero journal of pure and applied sciences, 1 (1): pp58-61.

[18] Waziri, M., Musa, U., Hatis, S. S. (2012) Assessment of Fluoride concentration in surface waters and groundwater sources in northeastern Nigeria: resources and environment 2 (2) pp 67-72.

[19] Dawoud, A. M., Raouf, A. R. A (2008) Groundwater exploration and assessment in rural communities of Yobe state northern Nigeria; water resources management vol. 23 issue 3 pp 581-601.

[20] Mante, M. A. (1986) Groundwater exploitation and drilling technology in Arid areas of Nigeria, Borno as a case study, proceedings of the first annual symposium and training workshop on groundwater resources in Nigeria pp141-173.

[21] Carter, J. D., Barber, W., Tait, E. A., Jones, G. P. (1963) The geology of parts of Adamawa, Bauchi and Borno provinces in northeastern Nigeria: Geol. Survey Niger Bull 30: 108 p.

[22] Offodile, M. E. (2002): An Approach to Groundwater Study and Development in Nigeria Second edition: Published Mecon Geology and Engineering Services Ltd. Jos, Nigeria. 453p.

[23] Obaje, N. G. (2009) Geology and mineral resources of Nigeria: springer $219 \mathrm{p}$.

[24] Linthurst, R. A., Bourdeau, P., Tardill, R. G. (1995) Methods to assess the effects of chemicals on ecosystems, chichester. UK; John Wiley and Sons.

[25] Kundu, N., Panigrahi, M. K., Tripathy, S., Munshi, S., Powell, M. A.,Hart, B. R.,(2001) Geochemical appraisal of Fluoride contamination of groundwater in the Nayagath district of Orissa. India environ geol vol. 41 (3) pp 451-460.

[26] Sivasankar, V., Darchen, A., Omine, K., Sakthivel, R., (2016) Fluoride: a world Ubiquitous compound, its chemistry, and ways of contamination. Springer international publishing Switzerland. pp 6-32.

[27] Reddy, D. V., Nagabhushanam, P., Sukhija, B. S., Reddy, A. G. S., Smedley, P. L. (2010) Fluoride dynamics in the granitic aquifers of the Wailapally watershed. Nalgonda district: India chem geol: 269 (3-4): pp 278-289.

[28] Yusuf, A. K., Goni, I. B., Hassan, M. (2014) Hydrochemical studies of the groundwater resources of the middle zone aquifer in southeastern Chad basin: IOSR journal of applied geology and geophysics vol. 2issue 2 ver.1 pp61-66.

[29] Wang, W., Li, R., Tan, J., Luo, K., Yang, L., Li, H., Li, Y. (2002) Adsorption and leaching of Fluoride in soils of China: Fluoride, 35 (2): pp 122-129. 